\title{
Karakter Morfo-fisiologi dan Hasil Padi Gogo Toleran Kekeringan
}

\section{(Morpho-physiological and Yield Characters of Upland Rice Tolerant to Drought)}

\author{
Yugi Rahayu Ahadiyat*, Sapto Nugroho Hadi, Okti Herliana
}

(Diterima Januari 2020/Disetujui Mei 2020)

\begin{abstract}
ABSTRAK
Tujuan penelitian ini adalah untuk mendapatkan varietas padi gogo yang berdaya hasil tinggi dengan karakter morfo-fisiologi yang mendukung hasil pada kondisi kekeringan. Sebelas varietas padi gogo dikarakterisasi berdasarkan sifat morfo-fisiologi dan hasil. Percobaan menggunakan Rancangan Acak Kelompok yang diulang tiga kali. Perlakuan terdiri atas sebelas varietas padi gogo, yaitu Gilirang, Situ Patenggang, Kalimutu, Aek Sibundong, Batutegi, Towuti, Sunggal, Danau Gaung, Way Apo Buru, Danau Tempe, dan Situ Bagendit. Parameter yang diamati adalah karakter morfologi, karakter fisiologi, dan karakter komponen hasil. Karakter morfologi yang diamati ialah tinggi tanaman, jumlah daun, luas daun, biomasa kering tajuk, jumlah anakan, dan total panjang akar. Karakter fisiologi yang diamati terdiri atas laju pertumbuhan tanaman, laju asimilasi bersih, dan laju pertumbuhan relatif. Karakter komponen hasil yang diamati ialah jumlah malai, panjang malai, jumlah biji per malai, bobot 1000 biji, bobot biji per rumpun, bobot biji per petak, dan bobot biji per hektar. Hasil penelitian menunjukkan bahwa Varietas Danau Tempe memiliki karakter yang lebih baik untuk menghadapi cekaman kekeringan dibandingkan dengan varietas lainnya dengan daya hasil yang lebih tinggi yang didukung oleh laju pertumbuhan tanaman, laju pertumbuhan relatif, kadar klorofil, dan luas daun yang tinggi dengan akumulasi kadar prolin dan panjang akar yang rendah.
\end{abstract}

Kata kunci: hasil, karakter morfo-fisiologi, kekeringan, varietas padi gogo

\section{ABSTRACT}

The objective of this study was to obtain varieties with high yield along with proper morpho-physiological characters under drought condition. Eleven varieties of upland rice i.e., Gilirang, Situ Patenggang, Kalimutu, Aek Sibundong, Batutegi, Towuti, Sunggal, Danau Gaung, Way Apo Buru, Danau Tempe, and Situ Bagendit were characterized based on morphology, physiology, and yield. Non factorial Complete Randomized Block Design was used with three times repetition. Parameters measured were morphological characters, physiological characters, and yield components. Morphological characters measured were plant height, number and area of leaf, shoot dry biomass, tiller number, and total root length. Physiological characters measured were plant growth rate, net assimilation rate, and relative growth rate. Yield components measured were number and length of panicle, number of seeds per panicle, 1000 seeds weight, weights of seed per panicle, weights of seed per plot, and weights of seed per hectare. The results showed that Danau Tempe variety had better characters against drought stress compared to the other varieties with higher yields supported by high plant growth rate, relative growth rate, chlorophyll content and leaf area with low accumulation of proline content and short root length.

Keywords: drought, morphological character, upland rice variety, yield

\section{PENDAHULUAN}

Agenda Riset Nasional tahun 2014-2019 menyebutkan untuk meningkatkan produksi dan produktivitas padi dapat dilakukan salah satunya melalui pengembangan padi gogo varietas unggul spesifik lokasi yang tahan cekaman abiotik, toleran tanah masam, dan mutu baik. Data terbaru pada tahun 2018 menunjukkan bahwa potensi luas total lahan kering di Indonesia mencapai 187,75 juta ha dan 67,37 juta ha di antaranya merupakan lahan kering nonhutan (BPS

Laboratorium Agroekologi, Fakultas Pertanian, Universitas Jenderal Soedirman, Jl. Dr. Soeparno No. 61, Karangwangkal, Purwokerto 53213

* Penulis Korespondensi:

Email: ahadiyat_yugi@yahoo.com
2020). Akan tetapi, potensi lahan kering di banyak daerah belum dimanfaatkan secara optimal untuk pengembangan tanaman padi dan tanaman pangan lainnya. Sampai saat ini, kontribusi produksi padi gogo baru mencapai 4-5\% (BPS \& Kementan 2017).

Karakter lahan kering berisiko mengalami kekeringan pada saat intensitas curah hujan rendah dan kahat unsur hara karena kondisi tanah masam. Hal ini menyebabkan ketersediaan unsur hara, khususnya fosfor (P), menjadi rendah karena terikat secara khusus oleh ion Al sehingga membentuk senyawa fosfat yang sukar larut (Yang et al. 2013). Ketidaktersediaan air pada fase pertumbuhan tertentu akan menyebabkan kematian (Guimaraes et al. 2016).

Akan tetapi, penelitian yang mengkaji karakter morfo-fisiologi spesifik setiap varietas terhadap karakter yang adaptif dengan tipologi lahan kering 
(cekaman kekeringan) masih belum banyak dilakukan. Hal yang menarik adalah bahwa karakter morpofisiologi spesifik tiap genotipe sangat berbeda dan tidak bisa digunakan sebagai acuan untuk genotipe lainnya (Ozturk et al. 2005). Oleh karena itu, perlu dilakukan identifikasi karakter morfo-fisiologi spesifik dan hasil setiap varietas padi gogo yang adaptif lahan kering dengan karakter tanaman yang toleran kekeringan sesuai dengan tipologi lingkungannya.

\section{METODE PENELITIAN}

Percobaan ini menguji sebelas varietas potensial, yaitu Gilirang, Situ Patenggang, Kalimutu, Aek Sibundong, Batutegi, Towuti, Sunggal, Danau Gaung, Way Apo Buru, Danau Tempe, dan Situ Bagendit yang dilakukan di lahan kering/tadah hujan jenis tanah inceptisol, di Desa Banjarsari Wetan, Kabupaten Banyumas selama bulan Mei-Agustus 2014. Selama penelitian berlangsung, suhu udara normal, kelembapan udara relatif rendah, dan intensitas curah hujan sangat rendah per bulan (Tabel 1). Penelitian ini dilakukan dengan menggunakan rancangan acak kelompok yang diulang tiga kali, dengan ukuran petak percobaan $2 \times 4 \mathrm{~m}^{2}$.

Karakter morfologis yang diamati meliputi total panjang akar tanaman padi gogo yang diukur pada saat fase akhir vegetatif umur 9 minggu setelah tanam (MST) pada saat pertumbuhan akar mencapai tingkat maksimal. Sampel yang diambil secara acak dalam setiap petak percobaan adalah sebanyak tiga rumpun tanaman padi. Tiap rumpun padi yang diambil kemudian dipotong dan diambil bagian akarnya saja. Setelah itu, bagian akarnya dicuci bersih dan dipotongpotong dengan ukuran kecil kurang lebih 1-2 cm. Setiap potongan akar kemudian dihitung dengan sistem intersection pada kertas millimeter blok dan dihitung dengan menggunakan hand counter. Rumus yang digunakan untuk menghitung panjang akar adalah:

$$
R=0,786 \times N \times G(\text { Bohm 1979) }
$$

\section{Keterangan:}

$\mathrm{R}=$ Panjang akar

$\mathrm{N}=$ Jumlah intersectios

$\mathrm{G}=$ Unit millimeter blok $\left(1 \mathrm{~cm}^{2}\right)$

Biomassa akar padi gogo ditimbang dalam bentuk bobot kering dan dilakukan setelah pengukuran total panjang akar selesai. Sampel akar tersebut dioven selama $18-20$ jam pada suhu $60-75^{\circ} \mathrm{C}$, setelah itu ditimbang sampai mencapai bobot konstan (Bohm 1979).

Sampel yang diambil untuk pengukuran dan pengamatan tinggi tanaman, jumlah dan luas daun, biomassa dan jumlah anakan diambil dari sampel yang sama dengan yang digunakan pada pengamatan karakter akar pada saat fase akhir vegetatif. Tinggi tanaman diukur mulai dari pangkal tanaman dari permukaan tanah sampai pada pucuk tertinggi dengan menggunakan meteran. Jumlah daun dihitung secara manual dan luas daun diukur dengan menggunakan leaf area meter di Laboratorium Pemuliaan Tanaman, Unsoed. Jumlah anakan dihitung langsung di lapangan secara visual dengan menggunakan handcounter. Biomassa tajuk diambil hanya bagian atasnya saja tanpa bagian akar tanaman. Sampel tersebut kemudian dioven selama 18-20 jam pada suhu 60$75^{\circ} \mathrm{C}$, setelah itu ditimbang untuk mendapatkan bobot kering biomassa tajuk.

Laju pertumbuhan tanaman, Iaju asimilasi bersih, dan laju pertumbuhan relatif dianalisis dengan menggunakan sampel yang sama dengan pengamatan karakter morfologi dengan rumus yang mengacu pada Hunt (1990). Analisis kandungan prolin (Bates et al. 1973) dan kadar klorofil (Wintermans \& De Mots 1965) diambil dari sampel daun pada saat akhir fase vegetatif (9 MST).

Sampel untuk pengukuran komponen hasil adalah sepuluh rumpun yang diamati pada saat menjelang panen pada karakter jumlah dan panjang malai. Sementara itu, karakter jumlah dan bobot biji per malai, bobot 1000 biji, bobot biji per rumpun, bobot biji per petak, dan bobot biji per hektar dihitung dengan menimbang hasil biji pada petak efektif yang menyisakan satu baris terluar dari setiap petak percobaan. Biji yang ditimbang untuk mengetahui bobotnya dikeringkan sampai mencapai kadar air 14\%.

Data yang diperoleh dianalisis dengan menggunakan analisis varians $\left(F_{0,05}\right)$, untuk mengetahui tingkat signifikansi masing-masing varietas terhadap variabel yang diamati dengan menggunakan software CropStat 7.2 (International Rice Research Institute 2007). Apabila terdapat perbedaan yang nyata akan dilanjutkan dengan uji Duncan Multiple Range Test ( $\mathrm{P}$ $=0,05)$.

\section{HASIL DAN PEMBAHASAN}

Tabel 2 menunjukkan bahwa pertumbuhan tanaman padi gogo dengan potensi toleran kekeringan

Tabel 1 Data kondisi lingkungan bulanan selama penelitian berlangsung

\begin{tabular}{lccc}
\hline \multirow{2}{*}{ Bulan } & \multicolumn{3}{c}{ Kondisi lingkungan } \\
\cline { 2 - 4 } & Suhu $\left({ }^{\circ} \mathrm{C}\right)^{1}$ & Kelembapan $(\%)^{1}$ & ${\text { Curah hujan }(\mathrm{mm})^{2}}^{\mathbf{2}}$ \\
\hline Mei & 28,5 & 57,0 & 37,0 \\
Juni & 30,0 & 53,0 & 20,0 \\
Juli & 29,0 & 50,0 & 0,0 \\
Agustus & 29,0 & 50,0 &
\end{tabular}

Keterangan: 1 = Rata-rata bulanan dan 2 = Jumlah total bulanan. 
Tabel 2 Karakter morfologi varietas padi gogo potensi toleran kekeringan

\begin{tabular}{|c|c|c|c|c|c|c|c|c|c|c|c|c|c|}
\hline \multirow{3}{*}{ Varietas } & \multicolumn{13}{|c|}{ Variabel pengamatan } \\
\hline & \multicolumn{3}{|c|}{ Tinggi tanaman $(\mathrm{cm})$} & \multicolumn{3}{|c|}{ Jumlah daun } & \multicolumn{3}{|c|}{ Jumlah anakan } & \multicolumn{3}{|c|}{ Luas daun $\left(\mathrm{cm}^{2}\right)$} & $\begin{array}{c}\text { Total } \\
\text { panjang }\end{array}$ \\
\hline & $\begin{array}{c}3 \\
\text { MST }\end{array}$ & $\begin{array}{c}6 \\
\text { MST }\end{array}$ & $\begin{array}{c}9 \\
\text { MST }\end{array}$ & $\begin{array}{c}3 \\
\text { MST }\end{array}$ & $\begin{array}{c}6 \\
\text { MST }\end{array}$ & $\begin{array}{c}9 \\
\text { MST }\end{array}$ & $\stackrel{3}{\text { MST }}$ & $\begin{array}{c}6 \\
\text { MST }\end{array}$ & $\begin{array}{c}9 \\
\text { MST }\end{array}$ & $\begin{array}{c}3 \\
\text { MST }\end{array}$ & $\begin{array}{c}6 \\
\text { MST }\end{array}$ & $\begin{array}{c}9 \\
\text { MST }\end{array}$ & $\begin{array}{c}9 \\
\text { MST }\end{array}$ \\
\hline Gilirang & $15,33^{e}$ & $30,28^{g}$ & $45,72^{\dagger}$ & 5,23 & $21,33^{c}$ & $44,30^{\text {bd }}$ & 1,07 & $6,37^{\mathrm{cd}}$ & $14,10^{\text {cd }}$ & $1,71^{\mathrm{g}}$ & $108,37^{c}$ & $486,85^{\mathrm{c}}$ & $752,00^{\mathrm{e}}$ \\
\hline $\begin{array}{l}\text { Situ } \\
\text { Patenggang }\end{array}$ & $23,28^{b c}$ & $58,38^{b}$ & $84,05^{b}$ & 6,30 & $25,17^{\mathrm{bc}}$ & $63,30^{\mathrm{bc}}$ & 1,37 & $7,87^{\mathrm{bc}}$ & $20,43^{b}$ & $2,82^{\mathrm{cd}}$ & $292,29^{a}$ & $1492,21^{a}$ & $1852,52^{a b}$ \\
\hline Kalimutu & $26,07^{b}$ & $66,63^{a}$ & $105,43^{a}$ & 5,93 & $19,63^{c}$ & $28,00^{\mathrm{e}}$ & 1,37 & $5,67^{d}$ & $8,67^{\dagger}$ & $4,05^{a}$ & $313,84^{a}$ & $636,57^{\text {de }}$ & $778,28^{\mathrm{e}}$ \\
\hline $\begin{array}{l}\text { Aek } \\
\text { Sibundong }\end{array}$ & $20,60^{d}$ & $38,07^{\text {ef }}$ & $54,07^{\text {def }}$ & 7,07 & $43,47^{a}$ & $86,90^{\mathrm{a}}$ & 1,27 & $13,97^{\mathrm{a}}$ & $28,30^{\mathrm{a}}$ & $2,55^{\text {de }}$ & $326,25^{a}$ & $1132,38^{\mathrm{ab}}$ & $1694,27^{b}$ \\
\hline Batutegi & $16,13^{\mathrm{e}}$ & $44,80^{d}$ & $66,13^{c}$ & 4,67 & $13,03^{d}$ & $36,30^{\mathrm{e}}$ & 1,23 & $3,43^{\mathrm{e}}$ & $12,32^{\text {de }}$ & $2,14^{\dagger}$ & $113,82^{c}$ & $686,67^{\text {cde }}$ & $1276,00^{d}$ \\
\hline Towuti & $19,40^{d}$ & $35,97^{f}$ & $51,14^{\text {ef }}$ & 6,53 & $40,27^{a}$ & $98,90^{\mathrm{a}}$ & 1,33 & $12,63^{\mathrm{a}}$ & $32,30^{\mathrm{a}}$ & $2,35^{\text {ef }}$ & $251,63^{a}$ & $1015,74^{\mathrm{bcd}}$ & $1440.99^{c d}$ \\
\hline Sunggal & $21,45^{\mathrm{cd}}$ & $35,367^{\dagger}$ & $61,37^{\mathrm{cd}}$ & 7,73 & $44,57^{a}$ & $90,60^{a}$ & 2,13 & $14,20^{\mathrm{a}}$ & $29,53^{a}$ & $2,61^{\text {de }}$ & $268,94^{a}$ & $1248,49^{\mathrm{ab}}$ & $2039,40^{a}$ \\
\hline $\begin{array}{l}\text { Danau } \\
\text { Gaung }\end{array}$ & $29,23^{a}$ & $57,07^{b}$ & $89,40^{b}$ & 7,13 & $29,43^{b}$ & $61,40^{\mathrm{b}}$ & 1,57 & $9,13^{b}$ & $19,80^{b}$ & $3,40^{\mathrm{b}}$ & $329,39^{a}$ & $1100,40^{\mathrm{ab}}$ & $1651,47^{c}$ \\
\hline $\begin{array}{l}\text { Way Apo } \\
\text { Buru }\end{array}$ & $19,10^{d}$ & $36,08^{f}$ & $50,08^{\text {ef }}$ & 6,97 & $29,23^{b}$ & $59,10^{\mathrm{b}}$ & 1,60 & $8,37^{b}$ & $10,03^{\mathrm{ef}}$ & $2,33^{\text {ef }}$ & $163,47^{b}$ & $284,29^{e}$ & $1472,27^{c d}$ \\
\hline $\begin{array}{l}\text { Danau } \\
\text { Tempe }\end{array}$ & $25,80^{b}$ & $51,27^{c}$ & $85,34^{b}$ & 7,83 & $28,13^{b}$ & $55,10^{\mathrm{bcd}}$ & 2,17 & $8,70^{b}$ & $17,70^{\mathrm{bc}}$ & $3,08^{b c}$ & $329,34^{a}$ & $1055,68^{\mathrm{ab}}$ & $1311,07^{d}$ \\
\hline $\begin{array}{l}\text { Situ } \\
\text { Bagendit }\end{array}$ & $20,15^{d}$ & $39,34^{e}$ & $56,34^{\text {de }}$ & 7,17 & $37,90^{a}$ & $56,27^{\text {bcd }}$ & 1,77 & $12,03^{a}$ & $29,50^{a}$ & $2,33^{e f}$ & $258,80^{a}$ & $1136,27^{\mathrm{ab}}$ & $2112,20^{a}$ \\
\hline KK (\%) & 11,21 & 7,65 & 12,08 & 22,13 & 8,66 & 8,26 & 11,21 & 13,46 & 9,43 & 14,25 & 6,48 & 7,03 & 5,80 \\
\hline
\end{tabular}

yang ditanam di lahan kering menunjukkan hasil yang beragam dalam karakter morfologinya. Semua variabel pengamatan menunjukkan hasil yang berbeda nyata, kecuali jumlah daun dan jumlah anakan pada umur 3 MST. Varietas Towuti sampai akhir fase vegetatif, yaitu 9 MST, menunjukkan tinggi tanaman yang paling tinggi $(105,43 \mathrm{~cm})$ dengan jumlah daun, jumlah anakan, luas daun, dan total panjang akar yang rendah masingmasing 28,00; 8,67; 636,57; $\mathrm{cm}^{2}$; dan $778,28 \mathrm{~cm}$, dibandingkan dengan varietas lainnya.

Pada saat mencapai fase akhir vegetatif, varietas Gilirang, Aek Sibundong, Towuti, dan Way Apo Buru memiliki tinggi tanaman yang rendah, yaitu $<55 \mathrm{~cm}$, yang berbeda nyata dibandingkan dengan varietas lainnya, terutama varietas Kalimutu dengan tinggi tanaman yang paling tinggi, yaitu $>100 \mathrm{~cm}$. Akan tetapi, hanya varietas Aek Sibundong yang memiliki jumlah daun, jumlah anakan, luas daun, dan total panjang akar yang tinggi, yaitu masing-masing $>85,>28,>1100 \mathrm{~cm}^{2}$, dan $>1600$ yang diikuti oleh varietas Towuti yang tinggi pada jumlah daun dan jumlah anakan, yaitu $>95$ dan $>30$, yang berbeda nyata dibandingkan dengan varietas lainnya (Tabel 2).

Varietas padi gogo dengan tinggi tanaman sedang ialah Sunggal yang berada pada kisaran tinggi $50-70$ $\mathrm{cm}$ dan memiliki jumlah daun, jumlah anakan, luas daun, dan total panjang akar yang cukup tinggi yang secara berturut-turut sebesar $>90,>29,>1100 \mathrm{~cm}^{2}$, dan $>2000 \mathrm{~cm}$. Karakter yang sama juga ditunjukkan oleh varietas Situ Bagendit, namun varietas ini rendah dalam jumlah daun, yaitu $<60$. Varietas Situ Patenggang, Danau Gaung, dan Danau Tempe memiliki tinggi tanaman yang cukup tinggi, yaitu antara 80-90 cm dan memiliki karakter jumlah daun sedang, yaitu antara 55-65, dan jumlah anakan yang cukup banyak, yaitu antara 17-21, namun memiliki luas daun dan total panjang akar yang tinggi, yaitu masingmasing $>1100 \mathrm{~cm}^{2}$ dan $1300-1800 \mathrm{~cm}$. Hal ini menunjukkan bahwa pada varietas tersebut terdapat karakter yang berbeda nyata dibandingkan dengan varietas Towuti, Gilirang, Aek Sibundong, dan Way Apo Buru (Tabel 2).

Keragaman yang menunjukkan perbedaan yang nyata ditunjukkan antar-varietas. Terdapat varietas padi yang memiliki tinggi tanaman rendah, yakni $<60$ $\mathrm{cm}$, namun memiliki jumlah daun, jumlah anakan, luas daun, dan total panjang akar yang tinggi, seperti varietas Aek Sibundong dan Towuti. Akan tetapi, ada perbedaan yang nyata dibandingkan dengan varietas Gilirang yang memiliki tinggi tanaman, jumlah daun, jumlah anakan, luas daun, dan total panjang akar yang rendah. Fenomena lain juga terlihat pada varietas Kalimutu yang memiliki tinggi tanaman $>100 \mathrm{~cm}$ dan termasuk ke dalam kategori tinggi dengan jumlah daun, jumlah anakan, luas daun, dan total panjang akar yang rendah. Karakter lain yang muncul adalah bahwa varietas Situ Patenggang, Danau Gaung, dan Danau Tempe memiliki tinggi tanaman yang sedang, yaitu kurang lebih $80 \mathrm{~cm}$ dan memiliki jumlah daun, jumlah anakan, luas daun, dan total panjang akar yang cukup tinggi.

Karakter fisiologi tanaman padi gogo yang memiliki potensi toleran kekeringan yang ditanam di lahan kering menunjukkan hasil yang tidak berbeda nyata pada laju pertumbuhan tanaman, kecuali pada minggu ke-9, laju asimilasi bersih, dan laju pertumbuhan relatif pada 9 minggu setelah tanam (MST). Laju pertumbuhan pada 3 dan 6 MST menunjukkan laju yang konstan dengan nilai 0,28 pada semua varietas yang diuji. Akan tetapi, pada 9 MST terlihat adanya keragaman hasil yang menunjukkan adanya perbedaan yang nyata pada laju pertumbuhan yang tinggi pada varietas Sunggal dan Way Apo Buru, yaitu 0,92. Varietas lainnya menunjukkan laju pertumbuhan sedang sampai rendah, yaitu $<0,75$ kecuali varietas Danau Gaung yang menunjukkan hasil yang tidak berbeda nyata dibandingkan dengan varietas Sunggal dan Way Apo Buru dengan nilai 0,82 (Tabel 3).

Laju asimilasi bersih pada dua pengamatan, yaitu pada 6 dan 9 MST, menunjukkan hasil yang tidak 
berbeda nyata, yaitu 0,0030-0,0075 pada semua varietas. Sementara itu, untuk laju pertumbuhan relatif pada 6 MST menunjukkan hasil yang tidak berbeda nyata dibandingkan dengan kisaran $0,59-0,91$, namun terdapat perbedaan yang nyata pada saat 9 MST dan varietas Batutegi dan Sunggal menunjukkan nilai tinggi masing-masing sebesar 1,010 dan 0,960, meskipun menunjukkan hasil yang tidak berbeda nyata dibandingkan dengan varietas Situ Patenggang $(0,84)$, Aek Sibundong $(0,90)$, Sunggal $(0,96)$, Danau Gaung $(0,77)$, Way Apo Buru $(0,84)$, Danau Tempe $(0,87)$, dan Situ Bagendit $(0,90)$ (Tabel 3).

Kandungan klorofil daun menunjukkan hasil yang tinggi pada varietas Kalimutu $\left(45,30 \mu \mathrm{g} \mathrm{mL}^{-1}\right)$ dan Danau Gaung $\left(44,83 \mu \mathrm{g} \mathrm{mL}^{-1}\right)$, meskipun tidak berbeda nyata dibandingkan dengan varietas Gilirang $(43,03 \mu \mathrm{g}$ $\left.\mathrm{mL}^{-1}\right)$, Aek Sibundong $\left(41,73 \mu \mathrm{g} \mathrm{mL}^{-1}\right)$, Sunggal $(44,2$ $\left.\mu \mathrm{g} \mathrm{mL}^{-1}\right)$, Way Apo Buru $\left(42,77 \mu \mathrm{g} \mathrm{mL}^{-1}\right)$, dan Danau Tempe $\left(42,17 \mu \mathrm{g} \mathrm{mL}^{-1}\right)$. Akan tetapi, varietas-varietas tersebut menunjukkan hasil yang tidak berbeda nyata dibandingkan dengan varietas Situ Patenggang, Batutegi, Towuti, dan Situ Bagendit (Tabel 3).

Untuk menganalisis keberadaan stres lingkungan, dilakukan pengamatan pada kandungan prolin pada daun. Hasil pengukuran menunjukkan bahwa akumulasi prolin yang tinggi terdapat pada varietas Kalimutu $\left(133,57 \mu \mathrm{M}\right.$ bobot basah $\left.{ }^{-1}\right)$ meskipun tidak berbeda nyata dibandingkan dengan Gilirang $(97,47$ $\mu \mathrm{M}$ bobot basah $\left.{ }^{-1}\right)$, Batutegi $\left(94,90 \mu \mathrm{M}\right.$ bobot basah $\left.^{-1}\right)$, dan Towuti $\left(129,90 \mu \mathrm{M}\right.$ bobot basah $\left.^{-1}\right)$. Akumulasi prolin yang rendah ditunjukkan oleh varietas Situ Patenggang, Sunggal, Danau Gaung, Way Apo Buru, Danau Tempe, dan Situ Bagendit yang berada pada kisaran 70-90 dan tidak berbeda nyata dibandingkan dengan varietas Kalimutu dan Aek Sibundong dengan nilai akumulasi prolin antara 93-95 $\mu \mathrm{M}$ bobot basah ${ }^{-1}$ (Tabel 3).

Pada karakter hasil dan komponen hasil terlihat bahwa tidak terjadi keragaman antar-varietas. Hanya karakter hasil tertentu yang menunjukkan perbedaan antara lain pada panjang malai, jumlah biji per malai, dan bobot biji per rumpun (Tabel 4). Panjang malai tertinggi dihasilkan oleh varietas Danau Gaung

Terdapat varietas yang memiliki tinggi tanaman yang rendah, yaitu $<60 \mathrm{~cm}$, namun memiliki jumlah daun, jumlah anakan, luas daun, dan total panjang akar yang tinggi, seperti varietas Aek Sibundong dan Towuti. Akan tetapi, ada juga varietas yang dengan tinggi tanaman yang rendah memiliki jumlah daun, jumlah anakan, luas daun, dan total panjang akar yang juga rendah, seperti varietas Gilirang.

Varietas Kalimutu yang memiliki tinggi tanaman $>100 \mathrm{~cm}$ dan termasuk ke dalam kategori tinggi memiliki jumlah daun, jumlah anakan, luas daun, dan total panjang akar yang rendah. Karakter lain yang muncul adalah bahwa varietas Situ Patenggang, Danau Gaung, dan Danau Tempe memiliki tinggi tanaman dalam kategori sedang, kurang lebih $80 \mathrm{~cm}$,

Tabel 3 Karakter fisiologi varietas padi gogo potensi toleran kekeringan

\begin{tabular}{|c|c|c|c|c|c|c|c|c|c|}
\hline \multirow{3}{*}{ Varietas } & \multicolumn{9}{|c|}{ Variabel pengamatan } \\
\hline & \multicolumn{3}{|c|}{ Laju pertumbuhan tanaman } & \multicolumn{2}{|c|}{ Laju asimilasi bersih } & \multicolumn{2}{|c|}{ Laju pertumbuhan relatif } & \multirow{2}{*}{$\begin{array}{c}\text { Klorofil daun } \\
\left(\mu \mathrm{gL} \mathrm{m}^{-1}\right)\end{array}$} & \multirow{2}{*}{$\begin{array}{c}\text { Prolin daun }(\mu \mathrm{M} \\
\left.\text { bobot basah }^{-1}\right)\end{array}$} \\
\hline & $3 \mathrm{MST}$ & 6 MST & 9 MST & $6 \mathrm{MST}$ & 9 MST & 6 MST & 9 MST & & \\
\hline Gilirang & 0,0039 & 0,0567 & $0,2100^{d}$ & 0,0069 & 0,0030 & 0,9133 & $0,4567^{c}$ & $43,03^{a b}$ & $97,47^{\mathrm{abc}}$ \\
\hline Situ Patenggang & 0,0084 & 0,0733 & $1,1367^{a b}$ & 0,0057 & 0,0067 & 0,7700 & $0,8433^{a b}$ & $40,67^{b}$ & $89,17^{c}$ \\
\hline Kalimutu & 0,0071 & 0,0867 & $0,3667^{c d}$ & 0,0050 & 0,0051 & 0,8500 & $0,4733^{c}$ & $45,30^{a}$ & $133,57^{a}$ \\
\hline Aek Sibundong & 0,0070 & 0,0567 & $0,8233^{\mathrm{abcd}}$ & 0,0056 & 0,0064 & 0,7067 & $0,8967^{a b}$ & $41,73^{a b}$ & $93,03^{b c}$ \\
\hline Batutegi & 0,0042 & 0,0567 & $0,6500^{\text {bcd }}$ & 0,0049 & 0,0079 & 0,5900 & $1,0133^{a}$ & $40,63^{\mathrm{b}}$ & $94,90^{\mathrm{abc}}$ \\
\hline Towuti & 0,0065 & 0,0733 & $0,3833^{\text {cd }}$ & 0,0066 & 0,0037 & 0,8333 & $0,5967^{\mathrm{bc}}$ & $40,83^{b}$ & $129,90^{\mathrm{ab}}$ \\
\hline Sunggal & 0,0080 & 0,0733 & $1,3467^{a}$ & 0,0043 & 0,0071 & 0,6767 & $0,9600^{\mathrm{a}}$ & $44,20^{\mathrm{ab}}$ & $87,37^{c}$ \\
\hline Danau Gaung & 0,0095 & 0,0633 & $0,6233^{b c d}$ & 0,0056 & 0,0050 & 0,6700 & $0,7667^{a b c}$ & $44,83^{a}$ & $88,17^{c}$ \\
\hline Way Apo Buru & 0,0054 & 0,0533 & $0,7067^{\text {bcd }}$ & 0,0070 & 0,0074 & 0,7900 & $0,8400^{\mathrm{ab}}$ & $42,77^{\mathrm{ab}}$ & $81,67^{c}$ \\
\hline Danau Tempe & 0,0061 & 0,0667 & $0,9433^{\mathrm{abc}}$ & 0,0063 & 0,0061 & 0,8567 & $0,8733^{a b}$ & $42,17^{\mathrm{ab}}$ & $74,27^{c}$ \\
\hline Situ Bagendit & 0,0365 & 0,0800 & $1,3400^{\mathrm{a}}$ & 0,0071 & 0,0072 & 0,8067 & $0,9033^{a b}$ & $40,3^{b}$ & $81,77^{\mathrm{c}}$ \\
\hline $\mathrm{KK}(\%)$ & 2,97 & 3,97 & 24,69 & 3,50 & 4,00 & 14,45 & 21,62 & 4,67 & 22,4 \\
\hline
\end{tabular}

Keterangan: MST = Minggu setelah tanam. Nilai yang diikuti dengan huruf yang sama pada kolom yang sama menunjukan hasil yang tidak berbeda nyata berdasarkan uji Duncan's Multiple Range Test $(P=0,05)$.

Tabel 4 Karakter hasil dan komponen hasil varietas padi gogo potensi toleran kekeringan

\begin{tabular}{|c|c|c|c|c|c|c|c|}
\hline \multirow[b]{2}{*}{ Varietas } & \multicolumn{7}{|c|}{ Variabel pengamatan } \\
\hline & $\begin{array}{c}\text { Jumlah } \\
\text { malai }\end{array}$ & $\begin{array}{c}\text { Panjang } \\
\text { malai }(\mathrm{cm})\end{array}$ & $\begin{array}{c}\text { Jumlah biji } \\
\text { malai }^{-1}\end{array}$ & $\begin{array}{c}\text { Bobot } 1000 \\
\text { biji (g) }\end{array}$ & $\begin{array}{l}\text { Bobot biji } \\
\text { rumpun-1 }(\mathrm{g})\end{array}$ & $\begin{array}{l}\text { Bobot biji } \\
\operatorname{petak}^{-1}(\mathrm{~g})\end{array}$ & $\begin{array}{l}\text { Bobot biji } \\
\text { ha }^{-1} \text { (ton) }\end{array}$ \\
\hline Gilirang & $14,67^{a}$ & $16,67^{\mathrm{cd}}$ & $74,33^{d}$ & 17,97 & $33,63^{a}$ & $896,43^{a}$ & $1,49^{a}$ \\
\hline Situ Patenggang & $14,67^{a}$ & $21,33^{b}$ & $139,67^{\mathrm{bc}}$ & 19,30 & $22,20^{\mathrm{c}}$ & $714,52^{b}$ & $1,19^{b}$ \\
\hline Kalimutu & $5,67^{b}$ & $20,67^{b}$ & $116,00^{c}$ & 17,70 & $13,13^{\mathrm{e}}$ & $561,04^{c}$ & $0,94^{\mathrm{bc}}$ \\
\hline Aek Sibundong & $23,00^{\mathrm{a}}$ & $16,00^{d}$ & $62,67^{d}$ & 14,28 & $11,83^{\mathrm{e}}$ & $510,41^{c d}$ & $0,85^{c}$ \\
\hline Batutegi & $17,00^{\mathrm{a}}$ & $21,33^{b}$ & $203,00^{a}$ & 14,73 & $23,07^{c}$ & $797,62^{a b}$ & $1,33^{a b}$ \\
\hline Towuti & $18,67^{a}$ & $18,33^{c}$ & $67,67^{\mathrm{d}}$ & 18,37 & $10,03^{f}$ & $519,97^{\mathrm{cd}}$ & $0,87^{c}$ \\
\hline Sunggal & $22,67^{a}$ & $17,00^{\mathrm{cd}}$ & $51,33^{d}$ & 18,63 & $8,00^{9}$ & $445,30^{e}$ & $0,74^{c}$ \\
\hline Danau Gaung & $13,00^{\mathrm{a}}$ & $24,00^{\mathrm{a}}$ & $128,33^{b c}$ & 17,33 & $9,53^{f g}$ & $468,97^{d}$ & $0,78^{c}$ \\
\hline Way Apo Buru & $18,00^{\mathrm{a}}$ & $17,67^{\mathrm{cd}}$ & $55,67^{d}$ & 18,83 & $17,43^{d}$ & $683,37^{\mathrm{bc}}$ & $1,14^{b}$ \\
\hline Danau Tempe & $15,67^{a}$ & $21,33^{b}$ & $146,33^{b}$ & 17,13 & $25,70^{b}$ & $878,33^{a}$ & $1,46^{a}$ \\
\hline Situ Bagendit & $21,67^{a}$ & $17,67^{\mathrm{cd}}$ & $60,33^{d}$ & 20,13 & $5,43^{h}$ & $438,64^{e}$ & $0,73^{c}$ \\
\hline $\mathrm{KK}(\%)$ & 13,79 & 5,75 & 15,99 & 24,90 & 20,07 & 5,34 & 25,05 \\
\hline
\end{tabular}

Keterangan: MST = Minggu setelah tanam. Nilai yang diikuti dengan huruf yang sama pada kolom yang sama menunjukan hasil yang tidak berbeda nyata berdasarkan uji Duncan's Multiple Range Test $(\mathrm{P}=0,05)$. 
tapi memiliki jumlah daun, jumlah anakan, luas daun, dan total panjang akar yang cukup tinggi. Tinggi tanaman pada berbagai penelitian sebelumnya menunjukkan respons yang berbeda pada varietas yang berbeda, namun diikuti dengan nilai yang bertolak belakang dengan karakter lainnya, seperti jumlah anakan (Suwarto 2003; Aldi et al. 2004; Hartati \& Suwarto 2004).

Fenomena di atas menunjukkan bahwa hubungan antar-karakter morfologi tidak sepenuhnya pasti, tetapi bergantung pada respons genetik yang diekspresikan oleh varietas tersebut. Tanaman dengan tinggi tanaman yang tinggi belum tentu memiliki karakter morfologi lain yang tinggi, begitu pun sebaliknya. Hal ini menjadi menarik karena seleksi terhadap tanaman, khususnya varietas padi gogo yang memiliki karakter morfologi yang sesuai untuk ditanam di lahan kering, perlu dilakukan secara teliti untuk mendapatkan karakter yang tepat. Ahmadikhah \& Marufinia (2016) menyatakan bahwa karakter tanaman padi yang tahan cekaman kekeringan ditunjukkan oleh parameter yang rendah dalam tinggi tanaman, jumlah anakan, dan biomasa, namun tinggi pada kadar klorofil.

Varietas Sunggal, selain memiliki karakter morfologi yang tinggi, ternyata juga didukung oleh karakter fisiologi dengan laju pertumbuhan, laju asimilasi bersih, laju pertumbuhan relatif, dan klorofil daun yang tinggi, namun rendah dalam kandungan prolin. Hal ini menunjukkan bahwa pertumbuhan varietas Sunggal berada dalam kondisi tidak tercekam, meskipun tumbuh dalam lingkungan yang kering. Berbeda dari varietas Kalimutu dan Towuti yang cenderung mengalami cekaman yang ditandai dengan kadar prolin yang tinggi, namun karakter laju pertumbuhan tanaman, laju pertumbuhan relatif, dan laju asimilasi bersih yang rendah. Peningkatan kadar prolin menunjukkan kemampuannya dalam meningkatkan toleransinya pada kondisi tercekam, namun tidak berarti signifikan pada hasil yang diperoleh. Akumulasi kadar prolin yang tinggi menunjukkan bahwa tanaman tersebut memiliki tingkat toleransi yang tinggi pada kondisi cekaman kekeringan (Gómez-Luciano et al. 2012).

Hal ini menunjukkan bahwa respons tanaman terhadap lingkungan tercekam kekeringan memberikan tanggap yang berbeda antar-varietas. Fathi \& Tari (2016) menyatakan bahwa mekanisme toleransi kekeringan pada setiap genotipe dipengaruhi oleh kerja gen. Ketahanan tanaman merupakan waktu yang dibutuhkan untuk merespons toleransi dan kemudian meningkatkan fleksibilitas sel terhadap kondisi kekeringan (Guimarães et al. 2016). Proses pemulihan dari kondisi kekeringan merupakan reaksi atau respons tanaman untuk menghasilkan antioksidan yang pada intinya memperlambat kerusakan membran sel (da Silva et al. 2013).

Varietas Sunggal dan Aek Sibundong memiliki karakter morpo-fisiologi yang lebih baik dibandingkan dengan varietas lainnya, namun memiliki daya hasil yang rendah $\left(<1 \mathrm{t} \mathrm{ha}^{-1}\right)$. Akan tetapi, berbeda dari varietas Danau Tempe yang memiliki karakter morpo- fisiologi yang mendukung kondisi cekaman kekeringan dan masih mampu menghasilkan produksi tinggi $\left(>1,25 \mathrm{t} \mathrm{ha}^{-1}\right)$. Karakter morfo-fisiologi yang ideal belum tentu mampu menghasilkan produksi yang tinggi. Produksi merupakan indikator yang paling penting untuk menunjukkan kemampuan atau daya adaptasi pada kondisi cekaman kekeringan setelah itu didukung oleh karakter fisiologi dan morfologinya (Sulistyono et al. 2012; Kumar et al. 2014; Navya et al. 2019).

\section{KESIMPULAN}

Varietas Danau Tempe menunjukkan karakter yang lebih baik menghadapi cekaman kekeringan dibandingkan dengan varietas lainnya dengan daya hasil $>1,25 \mathrm{t} \mathrm{ha}^{-1}$ yang didukung oleh laju pertumbuhan tanaman, laju pertumbuhan relatif dan klorofil yang tinggi masing-masing $>0,80,>0,80,>40 \mu \mathrm{g} \mathrm{mL}-1$, dengan kadar prolin rendah, yaitu $<95 \mu \mathrm{M}$ (bobot basah $)^{-1}$ serta luas daun tinggi $\left(>1000 \mathrm{~cm}^{-2}\right)$ dengan panjang akar rendah $(<1500 \mathrm{~cm})$.

\section{UCAPAN TERIMA KASIH}

Penulis sampaikan ucapan terima kasih yang sebesar-besarnya kepada LPPM Unsoed yang telah memberikan Hibah Riset Pemula Tahun Anggran 2014 sehingga penelitian bisa berjalan lancar dan mampu menghasilkan publikasi ilmiah.

\section{DAFTAR PUSTAKA}

Ahmadikhah A, Marufinia A. 2016. Effect of reduced plant height on drought tolerance in rice. 3 Biotech 6: 221. 1-9. https://doi.org/10.1007/s13205-0160542-3

Aldi MA, Darjanto, Totok ADH. 2004. Pengaruh cara pengendalian gulma terhadap hasil empat kultivar padi gogo. Agrin. 8(2): 100-107.

Bates LS, Wildren RP, Teary JD. 1973. Rapid determination of free proline for water-stress studies. Plant Soil. 39: 205-207. https://doi.org/ 10.1007/BF00018060

Bohm W. 1979. Methods of Studying Root Systems. Ecological Studies: Analysis and Synthesis. Vol. 33. Springer-Verlag. Berlin (DE). https://doi.org/ 10.1007/978-3-642-67282-8

[BPS] Badan Pusat Statistik. 2020. Luas penutupan lahan Indonesia di dalam dan di luar kawasan hutan Tahun 2014-2018. Jakarta (ID).

[BPS] Badan Pusat Statistik Kementan. 2017. Data Produksi Tanaman berdasarkan Komoditas. Jakarta (ID). 
da Silva EC, de Albuquerque MB, Neto ADA, Junior CDS. 2013. Drought and Its Consequences to Plants-From Individual to Ecosystem, In book: Responses of Organisms to Water Stress $1^{\text {st }}$ Edition. IntechOpen, 17-47. https://doi.org/10. $5772 / 53833$

Fathi A, Tari DB. 2016. Effect of drought stress and its mechanism in plants. International Journal of Life Sciences. 10(1): 1-6. https://doi.org/10.3126/ ijls.v10i1.14509

Gómez-Luciano LB, Hsieh CH, Wu CW. 2012. Proline Accumulation Role on Drought-Induced Rice Genotypes. In: Proceedings Plant Abiotic Stress Tolerance II Conference, 2012 February 22-25. Vienna (AZ).

Guimarães CM, de Castro AP, Stone LF, de Oliveira JP. 2016. Drought tolerance in upland rice: identification of genotypes and agronomic characteristics. Acta Scientiarum Agronomy. 38(2): 201-206. https://doi.org/10.4025/actasciagron. v38i2.27164

Hartati, Suwarto. 2004. Hasil dan kualitas dua varietas unggul padi gogo yang ditanam tumpangsari dengan perlakuan pupuk hayati. Agronomika. 4(1): $1-9$.

Hunt R. 1990. Basic Growth Analysis. London (EN): Cambridge University Press. https://doi.org/10. 1007/978-94-010-9117-6

[IRRI] International Rice Research Institute. 2007. CropStat ver. 7.2. IRRI Los Banos. Philipines (PH).

Kumar S, Dwivedi SK, Singh SS, Jha SK, Lekshmy S, Elanchezhian R, Singh ON, Bhatt BP. 2014. Identification of drought tolerant rice genotypes by analyzing Drought tolerance indices and morphophysiological traits. SABRAO Journal of Breeding and Genetics. 46(2): 217-230.

Navya GT, Dushyanthakumar BM, Madhuri R, Shubha KN, Gangaprasad S. 2019. Studies on morphophysiological traits associated with drought tolerance in local landraces of rice (Oryza sativa L.). International Journal of Current Microbiology and Applied Sciences. 8(7): 1940-1951. https://doi.org/ 10.20546/ijcmas.2019.807.231

Ozturk L, Eker S, Torun B, Cakmak I. 2005. Variation in Phosphorous efficiency among 73 bread and durum wheat genotypes grown in a phosphorous deficiency calcareous soil. Plant Soil. 269: 69-80. https://doi.org/10.1007/s11104-004-0469-z

Sulistyono E, Suwarno, Lubis I. 2012. Karakterisasi morfologi dan fisiologi untuk mendapatkan marka morfologi dan fisiologi padi sawah tahan kekeringan (-30 kpa) dan produktivitas tinggi (>8 ton/ha). Jurnal IImu Pertanian Indonesia. 17(2): 96-102.

Suwarto. 2003. Penampilan sifat agronomik populasi $\mathrm{F}_{2}$ hasil persilangan danau tempe $\mathrm{x}$ mentikwangi dan resiproknya untuk perakitan gogo aromatik. Agronomika. 3(1): 54-62.

Wintermans JFGM, De Mots A. 1965. Spectrophotometric characteristics of chlorophylls a and $\mathrm{b}$ and their pheophytins in ethanol. Biochimica et Biophysica Acta. 109: 448-453. https://doi.org/ 10.1016/0926-6585(65)90170-6

Yang ZB, Rao IM, Horst WJ. 2013. Interaction of aluminium and drought stress on root growth and crop yield on acid soils. Plant Soils. 372: 3-25. https://doi.org/10.1007/s11104-012-1580-1 